\title{
MENINGKATKAN KEAKTIFAN SISWA DALAM PEMBELAJARAN DARING MELALUI MEDIA GAME EDUKASI QUIZIZ PADA MASA PENCEGAHAN PENYEBARAN COVID-19
}

\author{
oleh \\ Maria Simanjuntak, M.Pd., (mariasimanjuntak0@gmail.com) \\ SMA Negeri I Pancur Batu
}

\begin{abstract}
Abstrak-Penelitian ini bertujuan untuk mengetahui peningkatan keaktifan belajar dalam pembelajaran daring melalui media game edukasi quiziz. Penelitian ini merupakan penelitian tindakan kelas dengan subyek penelitian siswa kelas XII IIS 4 SMA Negeri 1 Pancur Batu sebanyak 36 orang siswa. Penelitian ini dilaksanakan 2 siklus, masing-masing siklus 2 kali pertemuan. Setiap pertemuan terdisi dari 4 tahap yaitu perencanaan, pelaksanaan, observasi dan refleksi. Pelaksanaan tahap-tahap penelitian sedikit berbeda dari pembelajaran dalam kelas karena pembelajara dilakukan secara terpisah atau siswa berada di rumah masingmasing. Berdasarkan hasil penelitian, pada siklus I diperoleh rata-rata siswa yang aktif 52,25\% dengan katagori cukup. Sedangkan pada siklus II diperoleh rata-rata siswa aktif 73,9 $\%$ dengan katagori tinggi. Jadi dari siklus I dan siklus II terjadi peningkatan keaktifan siswa 17,65\%. Dengan demikian penelitian dapat disimpulkan bahwa media game edukasi quiziz dapat meningkatkan keaktifan siswa dalam pembelajaran daring pada masa pencegahan penyebaran Covid-19 mata pelajaran Bahasa Indonesia.
\end{abstract}

\section{Kata Kunci: Keaktifan Belajar, Pembelajaran Daring, Media Game.}

\section{A. PENDAhuluan}

Belajar merupakan kegiatan utama dari keseluruhan proses pendidikan di sekolah yang bertujuan untuk menghasilkan perubahan tingkah laku. Perubahan itu meliputi kognitif, afektif dan psikomotor. Kegiatan pembelajaran memerlukan keaktifan belajar, partisipasi dan komunikasi interaktif antara guru dan siswa. Aktivitas belajar dirancang sedemikian rupa sehingga menghasilan pembelajaran yang ditentukan. Keberhasilan dalam proses pembelajaran dapat dilihat dari pemahaman konsep, penguasaan materi dan prestasi belajar. Siswa dengan tingkat pemahaman konsep dan penguasaan materi yang tinggi maka semakin tinggi prestasi. Selain itu faktor penentu keberhasilan pembelajaran adalah ketepatan penerapan model dan media pembelajaran. Seorang guru diharuskan memahami metode pembelajaran terutama yang berkaitan dengan model-model pembelajaran.

Manfaat media pembelajaran adalah memperjelas penyajian pesan dan informasi sehingga dapat memperjelas dan meningkatkan proses dan hasil belajar. Media pembelajaran juga dapat mengarahkan perhatian siswa sehingga dapat menimbulkan motivasi belajar yang berdampak pada keaktifan dan hasil belajar. Pada era revolusi industri 4.0 merupakan tantangan dalam seluruh bidang ilmu secara khusus bidang pendidikan. Pendidikan memegang peranan penting suatu bangsa. Pendidikan adalah usaha sadar untuk menumbuhkembangkan potensi sumber daya manusia melalui pengajaran (Rohmah, 2017). Sesuai Undang-Undang sistem pendidikan nasional pasal 3 tentang 
fungsi dan tujuan pendidikan nasioanal adalah mengembangkan kemampuan dan membentuk watak dan peradaban bangsa yang bermanfaat dalam mencerdaskan kehidupan bangasa. Pendidikan nasional juga bertujuan untuk mengembangkan potensi siswa agar menjadi manusia yang beriman dan bertqwa kepada Tuhan Yang Maha Esa, berakhak mulia, sehat,berilmu, cakap, kreatif, mandiri, dan menjadi warga negara yang demokratis dan bertangung jawab. Tujuan inilah yang mendasari peningkatan mutu pendidikan di Indonesia.

Peningkatan mutu pendidikan dapat dilakukan dengan melakukan pembaharuan dalam proses pembelajaran, salah satunya adalah penerapan media pembelajaran. Untuk menjawab tantangan era revolusi industri 4.0, guru harus mampu berinovasi dalam penerapan media pembelajaran untuk meningkatkan motivasi dan keaktifan siswa yang berdampak pada hasil belajar.

Penularan COVID-19 sangatlah cepat sehingga Organisasi Kesehatan Dunia (WHO) menetapkan virus corona atau COVID-19 ini sebagai pandemi pada tanggal 11 Maret 2020. Status epidemi global atau pandemi ini menandakan penyebaran COVID-19 berlangsung sangatlah cepat hingga hampir tak ada negara di dunia yang dapat terhindar dari virus corona. COVID-19 telah menjadi pandemi, sehingga pemerintah di berbagai negara telah menerapkan lockdown atau karantina. Pengertian karantina menurut UU Republik Indonesia Nomor 6 tahun 2018 tentang kekarantinaan kesehatan adalah pembatasan kegiatan dan/atau pemisahan seseorang yang terpapar penyakit menular sebagaimana ditetapkan dalam peraturan perundang-undangan meskipun belum menunjukkan gejala apapun untuk mencegah kemungkinan penyebaran ke orang di sekitarnya (UU No 6 tahun 2018). Pemerintah Indonesia telah mengimbau untuk tetap di dalam rumah dan mengisolasi diri. Pemerintah Indonesia menerapkan aturan PSBB yang merupakan singkatan dari Pembatasan Sosial Berskala Besar yang dibuat dalam rangka Penanganan COVID-197. Hal ini dilakukan dengan harapan virus tidak menyebar lebih luas dan upaya penyembuhan dapat berjalan maksimal. Dalam usaha pembatasan sosial ini pemerintah Indonesia telah membatas kegiatan di luar rumah seperti kegiatan pendidikan yang telah dilakukan secara online melalui pembelajaran online

Pembelajaran online dilakukan dengan memanfaatkan teknologi khususnya internet. Pembelajaran online dilakukan dengan sistem belajar jarak jauh, dimana Kegiatan Belajar dan Mengajar (KBM) tidak dilakukan secara tatap muka.

Pada pembelajaran online, peserta didik dapat menjadi kurang aktif dalam menyampaikan aspirasi dan pemikirannya, sehingga dapat mengakibatkan pembelajaran yang menjenuhkan. Seorang siswa yang mengalami kejenuhan dalam belajar akan memperoleh ketidakmajuan dalam hasil belajar. Oleh karena itu, diperlukan pendorong untuk menggerakan siswa agar semangat belajar sehingga dapat memiliki prestasi belajar. Semangat belajar dapat dimiliki dengan meningkatkan motivasi belajar. Motivasi belajar adalah sebuah penggerak atau pendorong yang membuat seseorang akan tertarik kepada belajar sehingga akan belajar secara terus-menerus. Motivasi yang rendah dapat menyebabkan rendahnya keberhasilan dalam belajar sehingga akan merendahkan prestasi belajar siswa. Oleh karena itu, dalam penelitian kali ini akan membahas 
mengenai bagaimana cara meningkatkan motivasi belajar siswa pada pembelajaran online akibat pandemi COVID-19. Berdasarkan hasil observasi, siswa yang memiliki smartphone hanya dimanfaatkan untuk membaca berbagai media sosial dan bermain game. Siswa belum paham bahwa smartphone sangat bermanfaat dalam dunia pendidikan, bahkan siswa belum banyak tahu tentang media game edukasi terutama kelas XII

Memasuki bulan Maret 2020 di Indonesia menyebarlah isu penyebaran Covid-19. Bukan isapan jempol belaka,virus ini di akhir tahun 2019 terjadi kasus terinfeksi pertama di negara Cina yaitu kota Wuhan yang kemudian menyebar keseluruh dunia termasuk Indonesia. Salah satu cara mencegah penyebaran wabah Covid-19 antar manusia adalah tidak berinteraksi secara langsung dan menjaga jarak satu sama lain.Dalam rangka melaksanakan pencegahan ini , maka Dinas Pendidikan provinsi Sumatera Utara mewajibkan siswa belajar dirumah dalam waktu yang relatif lama. Belajar siswa dirumah diawasi orang tua dan dipandu oleh guru mata pelajaran secara daring. Hal ini menjadi tantangan bagi guru untuk tetap dapat menciptakan pembelajaran yang menyenangkan, menarik dan aktif. Walaupun pembelajaran dilaksanakan jarak jauh atau daring, guru harus mampu meningkatkan keaktifan siswa. Keaktifan siswa dapat tercipta melalui penerapan media pembelajaran yang menarik.

Salah satu media pembelajaran yang menarik dalam pembelajaran daring adalah memanfaatkan game edukasi quiziz. Game edukasi ini masih jarang ditemui meskipun sudah ada namun pemanfaatan dalam media pembelajaran sangat kurang. Game edukasi quiziz ini biasa menggunakan Laptop atau smartpone dan dapat dilaksanakan dimanapun berada. Game edukasi ini sebagai media pembelajaran yang diintegrasikan dengan soal- soal evaluasi diharapkan dapat membuat pembelajaran lebih menarik,menyenangkan dan aktif. Hal ini sependapat dengan Henry (2010) mengemukakan tentang dampak positif penggunaan game yang salah satunya adalah game menyenangkan dan menghibur serta game yang memberikan latihan untuk memecahkan masalah dan logika sehingga terbiasa aktif berpikir, belajar dan berlatih walaupun berada dirumah.

Berdasarkan uaraian di atas, maka yang menjadi rumusan masalah dalam penelitian tindakan kelas adalah:

1. Apakah dengan mengunakan metode Game Edukasi dapat meningkatkan keaktifan siswa dalam belajar selama masa pandemi Covid 19?

2. Bagaimana cara menggunakan metode Game Edukasi ini dalam pembelajaran?

3. Bagaimanakah hasil pembelajaran siswa setelah menggunakan metode Game edukasi?

Sesuai dengan rumusan masalah di atas maka dapatlah ditentukan tujuan Penelitian Tindakan Kelas ini sebagai berikut:

1. Untuk menegetahui peningkatan kektifan siswa dalam belajar dengan menggunakan metode Game Edukasi.

2. Untuk mengetahui cara penerapan Game Edukasi dalam pembelajaran.

3. Untuk menegetahui hasil pembelajaran siswa setelah menggunakan metode game edukasi.

Adapun manfaat dari penelitian ini adalah sebagai berikut: 
1. Bagi siswa, melalui metode Game Edukasi ini diharapkan keaktifan belajar selama pandemi Covid 19 ini semakain meningkat.

2. Bagi guru, menjadi bahan masukan bagi guru tentang pemanfaatan metode Game Edukasi ini dalam menigkatkan keaktifan belajar siswa di rumah.

3. Bagi sekolah, agar dapat memberikan informasi tentang pemanfaatan metode belajar yang kreatif dalam meningkatkan keaktifan siswa belajar selama masa Covid 19.

Belajar dalam Kamus Besar Bahasa Indonesia, secara etimologis memiliki arti "berusaha memperoleh kepandaian atau ilmu". Definisi ini memiliki pengertian bahwa belajar adalah sebuah kegiatan untuk mencapai kepandaian atau ilmu. Belajar menurut Baharuddin dan Esa (2009: 11) merupakan proses manusia untuk mencapai berbagai macam kompetensi, keterampilan, dan sikap. Belajar dimulai sejak manusia lahir sampai akhir hayat. Pengertian belajar menurut Oemar Hamalik (2001: 27) adalah modifikasi atau memperteguh kelakuan melalui pengalaman (learning is defined as the modification or strengthening of behavior through experiencing). Menurut pengertian ini, belajar merupakan suatu proses, suatu kegiatan dan bukan suatu hasil atau tujuan. Belajar bukan hanya mengingat, akan tetapi lebih luas dari itu, yakni mengalami. Hasil belajar bukan suatu penguasaan hasil latihan melainkan pengubahan kelakuan. Aunurrahman (2016: 35) menyatakan bahwa belajar adalah suatu proses yang dilakukan individu untuk memperoleh suatu perubahan tingkah laku yang baru secara keseluruhan, sebagai hasil pengalaman individu itu sendiri di dalam interaksi dengan lingkungannya. Menurut
Budiningsih dalam Jamil Suprihatiningrum (2014: 15) "Belajar merupakan suatu proses pembentukan pengetahuan, yang mana siswa aktif melakukan kegiatan, aktif berfikir, menyusun konsep, dan memberi makna tentang hal-hal yang sedang dipelajari.

Proses belajar terjadi karena adanya interaksi seseorang dengan lingkungannya. Oleh karena itu, belajar dapat terjadi dimana saja dan kapan saja. Interaksi ini membentuk pengalaman belajar yang juga akan berpengaruh terhadap pembentukan kemampuan. Kegiatan belajar mengajar seperti mengorganisasi pengalamn belajar, mengolah kegiatan belajar mengajar, menilai proses dan hasil belajar, kesemuanya termasuk dalam cakupan tanggung jawab guru. Jadi, hakikat belajar adalah perubahan. Belajar adalah segenap rangkaian kegiatan atau aktivitas yang dilakukan secara sadar oleh seseorang dan mengakibatkan perubahan dalam dirinya berupa penambahan pengetahuan atau kemahiran berdasarkan alat indra dan pengalamannya

Belajar merupakan suatu proses yang kompleks yang terjadi pada diri setiap orang sepanjang hidupnya. Proses belajar itu terjadi karena adanya interaksi antara sesorang dengan lingkungannya. Oleh karena itu, belajar dapat terjadi kapan saja dan dimana saja. Salah satu pertanda bahwa sesorang itu telah belajar adalah adanya perubahan tingkah laku pada diri orang itu yang mungkin disebabkan oleh terjadinya perubahan pada tingkat pengetahuan, ketrampilan, atau sikapnya (Azhar Arsyad, 2011:1). Dari uraian di atas dapat dikatakan bahwa belajar suatu proses yang sangat kompleks untuk mengubah manusia ke arah yang lebih baik. 
Aktivitas belajar adalah aktivitas yang bersifat fisik maupun mental. Dalam proses belajar kedua aktivitas itu harus saling berkaitan. Piaget (Sardiman, 2011.100) "menyatakan bahwa jika seorang anak berpikir tanpa berbuat sesuatu, berarti anak itu tidak berpikir". Aktivitas belajar dapat terjadi dari proses yang sangat informal sampai dengan yang sangat formal, dari bahan materi yang sangat sederhana sampai bahan materi yang rumit. Adapun menurut Sadirman (Nuraini, 2017, 8) “aktivitas dalam proses pembelajaran merupakan rangkaian kegiatan yang meliputi keaktifan siswa dalam mengikuti pelajaran, berpikir, membaca, dan segala kegaitan yang dilakukan yang dapat menunjang hasil belajar". Berdasarkan pendapat para ahli di atas, maka dapat disimpulkan bahwa aktivitas belajar merupakan serangkaian kegiatan pembelajaran (fisik maupun mental) yang dilakukan siswa selama proses pembelajaran. Dengan melakukan berbagai aktivitas dalam kegiatan pembelajaran diharapkan siswa dapat membangun pengetahuannya sendiri dengan bantuan guru.

Tidak ada belajar kalau tidak ada aktivitas. Itulah sebabnya aktivitas merupakan prinsip atau asas yang sangat penting di dalam interaksi belajarmengajar karena menunjang hasil belajar, apabila aktivitas belajar siswa itu baik maka hasil belajar yang akan dicapai juga baik dan sebaliknya apabila aktivitas belajar siswa itu kurang maka hasil belajar yang dicapai juga akan kurang.

$$
\text { Menurut Paul B. Diedrich }
$$
(Hanafiah dan Cucu Suhana, 2010, 24) menyatakan, aktivitas belajar dibagi ke dalam delapan kelompok, yaitu sebagai berikut: a. Kegiatan-kegiatan visual (visual activities), yaitu membaca, melihat gambar-gambar, mengamati eksperimen, demonstrasi, pameran dan mengamati orang lain bekerja atau bermain. b. Kegiatan-kegiatan lisan (oral avtivities), yaitu mengemukakan suatu fakta atau prinsip, menghubungkan suatu kejadian, mengajukan pertanyaan, memberi saran, mengemukakan pendapat, berwawancara diskusi dan interupsi. c. Kegiatan-kegiatan mendengarkan (listening aktivities), yaitu mendengarkan penyajian bahan, mendengarkan percakapan atau diskusi kelompok, atau mendengarkan radio. d. Kegiatan-kegiatan menulis (writing activities), yaitu menulis cerita, menulis laporan, memeriksa karangan, bahanbahan copy, membuat ouline atau rangkuman, dan mengerjakan tes serta mengisi angket e. Kegiatan-kegiatan menggambar (drawing aktivities), yaitu menggambar, membuat grafik, diagram, peta dan pola. f. Kegiatan-kegiatan motorik (motor activities), yaitu melakukan percobaan, memilih alat-alat, melaksanakan pameran, membuat model, menyelenggarakan permainan, serta menari dan berkebun. g. Kegiatan-kegiatan mental (mental activities), yaitu merenungkan, mengingat, memecahkan masalah, menganalisa faktor-faktor, melihat hubungan-hubungan, dan membuat keputusan. h. Kegiatan-kegiatan emosional (emotional activities), yaitu minat, membedakan, berani, tenang, merasa bosan dan gugup.

Adapun menurut Zulfikri (Basyuni Rosidin, 2011,9) jenis-jenis aktivitas dapat digolongkan menjadi: a. Visual Activities, yaitu segala kegiatan yang berhubungan dengan aktivitas siswa dalam melihat, mengamat, dan memperhatikan. b. Oral Activities, yaitu aktivitas yang berhubungan dengan kemampuan siswa dalam mengucapkan, melafazkan, dan 
berpikir. c. Listening Activities, aktivitas yang berhubungan dengan kemampuan siswa dalam berkonsentrasi menyimak pelajaran. d. Motor Activities, yakni segala keterampilan jasmani siswa untuk mengekspresikan bakat yang dimilikinya.

Berdasarkan uraian di atas dapat disimpulkan bahwa jenis aktivitas belajar adalah kegiatan-kegiatan yang dilakukan secara fisik ataupun non fisik sebagai suatu proses perubahan tingkah laku dan kemampuan individu dalam pembelajaran melalui interaksi dengan lingkungan sebagai hasil belajar mencakup aspek kognitif, afektif dan psikomotori

Game edukasi merupakan media pembelajaran yang sangat populer dan sedang banyak dikembangkan banyak ahli untuk mendukung proses pembelajaran di dalam kelas. Game edukasi merupakan sebuah permainan yang bertujuan memancing minat belajar anak sambil bermain, game edukasi sebenarnya lebih mengacu pada isi dan tujuan game, bukan termasuk dalam genre game yang sebenarnya dan bertujuan memancing minat anak sambil belajar. Oleh karena itu sangat diperlukan adanya sebuah media pembelajaran berupa game edukasi yang mampu memberi efek menarik dan menyenangkan bagi siswa dalam proses pembelajarannya, sehingga siswa mampu dengan mudah menerima materi yang diberikan oleh para pendidik. Media yang umumnya masih banyak digunakan saat ini adalah media berupa buku mata pelajaran. Buku merupakan media konvensional yang masih digunakan hingga saat ini. Kecenderungan membaca buku mata pelajaran pada siswa cenderung rendah. Rendahnya minat siswa membaca buku mata pelajaran dikarenakan buku merupakan media pembelajaran yang monoton, kurang menarik dan membosankan. Hal ini nantinya akan berpengaruh pada hasil belajar siswa

Menurut Romi Satria Wahono (ilmukomputer.com, 2007) game merupakan aktifitas terstruktur atau semi terstruktur yang biasanya bertujuan untuk hiburan dan kadang dapat digunakan sebagai sarana pendidikan. Karakterisitik game yang menyenangkan, memotivasi, membuat kecanduan dan kolaboratif membuat aktifitas ini digemari oleh banyak orang. Game merupakan sebuah permainan yang menarik dan menyenangkan. Game merupakan fenomena global. Permainan elektronik yang menggunakan media computer, phone seleluller maupun konsol seperti playstation atau $\mathrm{x}$-box sudah menjamur kemana-mana. Bisnis game juga sudah merambah kemana-mana, namun ironisnya konten dari game sebagian besar berisi hiburan dan sangat sedikit yang berkonten pendidikan (edukasi). Sebenarnya tanpa disadari game dapat mengajarkan banyak ketrampilan dan game dapat dijadikan sebagai salah satu alternatif pendidikan (Buckingham dan Scalon, 2002). Menurut Foreman (2009), game merupakan potential learning environments. Bermain game merupakan sebuah literatur baru dalam pendidikan.

Jadi media pelajaran mengunakan game adalah segala sesuatu yang dijadikan wahana, penghubung sehingga pesan yang disampaikan kepada peserta didik dapat tersampaikan dengan baik, yang dalam proses penyampaian pesan itu menggunakan permainan-permainan yang menggunakan teknologi yang dapat meransang peseta didik didalam memainkannya dalam rangka mempelajari memahami ilmu pengetahuan yang diajarkan oleh guru atau pendidik. 
Kecanggihan teknologi komunikasi memberi nuansa berbeda dalam proses belajar mengajar sesorang. Teknologi komunikasi mengubah lokasi belajar dari kelas ke tempat dimana saja pesertadidik dapat belajar. Dengan demikian, teknologi komunikasi mendorong terjadinya evolusi pada lokasi belajar. Menurut prawiradilaga belajar tidak lagi hanya berlangsung di sekolah dan di kelas, belajar dapat terjadi dimana saja selama ada bahan ajar dan peserta didik merasa nyaman dengan situasi itu. Disisi lain perkembangan teknologi telah menciptakan terobosanterobosan dalam pembelajaran. Peserta didik bersinggungan dengan perangkatperangkat teknologi komunikasi bergerak seperti handphone yang dengan berbagai fasilitasnya telah menjadi gelombang kecenderungan baru yang memungkinkan peserta didik (pembelajar) belajar secara mobile atau lebih dikenal sebagai mobile learning. Menurut Riyanto B dkk, mobile learning memungkinkan pembelajar dapat mengakses materi pembelajaran, arahan dan aplikasi yang berkaitan dengan materi pembelajaran kapan-pun dan dimana-pun. Walaupun sekarang mobile learning masih berada pada tahap awal pengembangan dan para peneliti masih mengeksplorasi setiap aspeknya, mobile learning akan menjadi cukup pesat dan viable dalam jangka waktu dekat dan menurut Crawford lingkungan yang penuh dengan pembelajaran dapat diciptakan melalui network device mobile lerarning. Pemanfaatan handphone sebagai sarana mobilitas dalam sebuah mobile learning dan penyajian materi dalam format game menjadi sebuah wacana untuk menyajikan pengetahuan dalam sebuah hiburan. Belajar dengan senang, belajar dimanapun kapanpun, tanpa sekat tanpa batas
Game yang berkembang saat ini didalam dunia pendidikan dikenal dengan game edukasi. Game edukasi ini bertujuan untuk memancing minat belajar siswa dalam memahami materi pembelajarn dengan sambil bermain, sehingga muncul perasaan senang, gembira, tidak membosankan. Maka dengan kondisi ini maka diharapkan anak termotifasi dan dengan mudah memahami pelajaran yang disampaikan oleh pendidik. Karena selama ini pembelajaran yang menggunakan media pembelajaran secara konvensional tidak melibatkan teknologi cenrung membuat anak didik bosan, jenuh didalam pembelajaran yang dilaksanakan di kelas.

Pemanfaatan game didalam pembelajaran saat ini cenrung mengalami perkembangan didalam dunia pendidikan dengan game edukasi yang melibatkan game atau permainan didalam proses pembelajaran yang dilakukan. Beberapa poin penting manfaat game juga dikemukakan pada forum Computer Assisted Investing Special Interest Group (SIG CAI) (uad.ac.id, 2009) adalah sebagai berikut:

1. Jenis games yang menuntut strategi penyelesaian masalah dapat meningkatkan kemampuan kognitif anak.

2. Laki-laki dan perempuan yang dilatih bermain video game selama 1 (satu) bulan menunjukkan peningkatan pada tes ingatan, dan kemampuan melakukan berbagai tugas (multi-task).

3. Video game dapat membuat pemainnya mempertajam cara pikir mereka.

4. Menuntut anak untuk lebih kreatif.

5. Dan juga anak dituntut untuk belajar mengambil keputusan dari segala tindakan yang dilakukan. 
6. Membangun semangat kerja sama atau teamworkketika dimainkan dengan gamers lainnya secaramultiplayer.

7. Mengembangkan kemampuan dalam membaca, matematika, dan memecahkan masalah atau tugas. Membuat anak-anak merasa nyaman dan familiar dengan teknologi terutama anak perempuan, yang tidak menggunakan teknologi sesering anak laki-laki.

8. Melatih koordinasi antara mata dan tangan, serta skill motorik.

9. Meningkatkan rasa percaya diri dan harga diri anak saat mereka mampu menguasai permainan.

\section{B. METODE PENELITIAN}

a. Jenis Penelitian

Penelitian ini adalah Penelitian Tindakan Kelas ( PTK) yang dikemukakan oleh Kemmist dan Taggart dalam bukunya Penelitian Tindakan Kelas $(2010,112)$, model penelitian ini terdiri dari empat komponen yaitu: 1. Perencanaan, 2. Tindakan, 3 Pengamatan, 4. Evaluasi/refleksi.

b. Lokasi dan Waktu Penelitian Penelitian ini dilaksanakan pada siswa kelas XII IIS 4 SMA Negeri I Pancur Batu tahun ajaran 2020/2021dan dilaksanakan di bulan Maret sampai dengan Juni 2020.

c. Subjek dan Objek Penelitian

Subjek dalam penelitian ini siswa kelas XII IIS 4 yang terdiri dari dari 36 siswa. Objek penelitian adalah pemanfaatan metode Game Edukasi dalam pelajaran Bahasa Indonesia di masa pademi Covid 19.

d. Desain Penelitian

Adapun desain penelitian tindakan kelas menurut Kemis dan Mc.
Tagggart di dalam buku Arikunto dilihat bagan skema di bawah ini:

Metode penelitian yang digunakan dalam penelitian ini adalah penelitian tindakan kelas untuk meningkatkan keaktifan siswa dalam pembelajaran daring melalui media game edukasi quiziz pada masa pencegahan penyebaran Covid-19 mata pelajaran Bahasa dan Sastra Indonesia. Penelitian ini dilakukan pada materi Surat Lamaran Kerja. Subyek penelitian adalah siswa kelas XII IIS 4 SMA Negeri I Pancur Batu yang melibatkan 36 siswa . Penelitian dilakukakan sejak dimulainya belajar dirumah sejak tanggal 17 Maret sampai tanggal 27 Juni 2020. Instrumen pengumpulan data adalah lembar observasi pelaksanaan proses pembelajaran daring melalui game edukasi quiziz, sedangkan teknis analisis data menggunakan teknik analisis deskriptif kualitatif dan kualitatif menggunakan kreteria pencapaian. Hasil penelitian dan pembahasan penelitian ini dilakasanakan 2 siklus yaitu siklus I dan siklus II masing masing siklus ada 2 kali pertemuan. Tahapan penelitian yang dilakukan pada siklus I pertemua ke-1 adalah:(1) tahap perencanaan yaitu menyiapkan lembar opservasi dan menyusun naskah soal untuk kuis, (2) tahap pelaksanaan yaitu memberikan file materi melalui Google Clasroom mengintruksikan dan membimbing pengunduhanaplikasi,memberikan kode link pengunduhan, (3) tahap observasi mengunduh hasil pekerjaan siswa, (4) refleksi. Tahap tahap ini juga dilakukan untuk pertemuan yang ke-2. Tahap-tahap penelitian ini sedikit berbeda karena pembelajaran bukan dalam kelas atau pembelajaran secara klasikal melainkan 
secara terpisah atau siswa berada di rumah masing-masing.

\section{HASIL PENELITIAN DAN PEMBAHASAN}

Berdasarkan hasil observasi pertemuan ke-1 dari 36 siswa hanya 20 $(55,5 \%)$ orang yang aktif, hal ini dapat dilihat dari hasil unduhan siswa yang mengerjakan kuis 1. Pertemuan ke-2 siswa yang aktif mengerjakan kuis 2 sebanyak 25 $(62,4 \%)$ siswa .Pada siklus I pertemuan ke-1 dan ke-2 rata-rata 58,9\% yang aktif. Hal ini dapat digambarkan pada tabel berikut ini:

$$
\text { Menurut Semiawan }
$$
keaktifan belajar dapat ditunjukkan oleh siswa dalam kegiatan belajar.

Tabel 1 Kategori Tingkat Keaktifan Siswa Belajar

\begin{tabular}{|c|l|l|}
\hline No & Rentang Nilai & Kategori \\
\hline 1 & $85 \%-100 \%$ & $\begin{array}{l}\text { Sangat } \\
\text { Tinggi }\end{array}$ \\
\hline 2 & $69 \%-84 \%$ & Tinggi \\
\hline 3 & $53 \%-68 \%$ & Sedang \\
\hline 4 & $37 \%-52 \%$ & Kurang \\
\hline 5 & $20 \%-36 \%$ & $\begin{array}{l}\text { Sangat } \\
\text { Kurang }\end{array}$ \\
\hline
\end{tabular}

Jadi hasil observasi pada siklus I menurut katagori di atas adalah termasuk katagori sedang. Setelah hasil diketahui maka perlu dilakukan refleksi untuk mengkoreksi kelemahan dan kendala yang terjadi pada siklus I kemudian mencari solusi yang nanti akan diterapkan pada siklus II dengan harapan hasilnya mengalami peningkatan. Dalam pelaksanaan siklus II, guru melakukan langkah-langkah yang sama dengan langkah-langkah pada siklus I, namun ada perbaikan pelaksanaan berdasarhan hasil refleksi pada siklus I.

Berdasarkan hasil pertemuan ke-1 pada siklus II siswa yang aktif mengerjakan kuis sebanyak $30(83,3 \%)$ siswa,sedangkan pada pertemuan ke-2 siswa yang aktif $28(77,7 \%)$ siswa.Ratarata hasil observasi pada siklus II adalah $80,5 \%$.Hasil siklus II termasuk dalam katagori tinggi. Dari hasil observasi suklus I dan siklus II keaktifan siswa mengalami peningkatan sebesar $24,4 \%$. Berikut tabel rekapitulasi keaktifan siswa kelas XII MIA 1 pada siklus I dan siklus II.

Tabel 2. Rekapitulasi Hasil Observasi Keaktifan Siswa.

\begin{tabular}{|c|c|c|l|l|l|}
\hline $\begin{array}{l}\text { N } \\
\text { o }\end{array}$ & $\begin{array}{l}\text { Siklu } \\
\text { s }\end{array}$ & $\begin{array}{l}\text { Pertem } \\
\text { uan } \\
\text { ke 1 }\end{array}$ & $\begin{array}{l}\text { Perte } \\
\text { muan } \\
\text { Ke 2 }\end{array}$ & $\begin{array}{l}\text { Ra } \\
\text { ta- } \\
\text { rat } \\
\text { a }\end{array}$ & $\begin{array}{l}\text { Kate } \\
\text { gori }\end{array}$ \\
\hline 1 & I & $55,5 \%$ & $\begin{array}{l}65,4 \\
\%\end{array}$ & $\begin{array}{l}58, \\
9 \\
\%\end{array}$ & $\begin{array}{l}\text { Cuk } \\
\text { up }\end{array}$ \\
\hline 2 & II & 83,3 & $\begin{array}{l}77,7 \\
\%\end{array}$ & $\begin{array}{l}80, \\
5\end{array}$ & $\begin{array}{l}\text { Ting } \\
\text { gi } \\
\%\end{array}$ \\
\hline 3 & $\begin{array}{l}\text { Peni } \\
\text { ngka } \\
\text { tan }\end{array}$ & & & $\begin{array}{l}24, \\
4 \\
\%\end{array}$ & \\
\hline
\end{tabular}

Berdasarkan table 2 diatas maka dapat digambarkan pada grafik sebagai berikut:

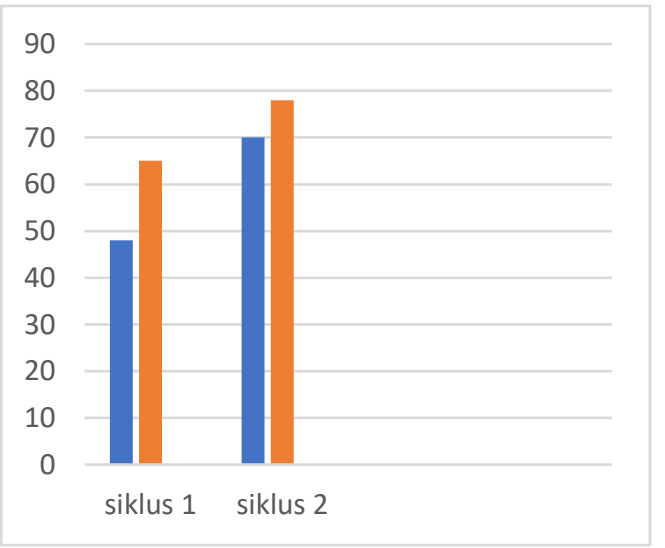

Grafik 1. Rekapitulasi Hasil Observasi Keaktifan Siswa 
Media game edukasi quiziz dapat meningkatkan keaktifan siswa pada masa pencegahan penyebaran Covid-19 mata pelajaran Bahasa Indonesia dalam pelajaran topik Surat Lamaran Kerja karena dalam pelaksanaanya seolah-olah membawa aktivitas multi permainan dan membuat pembelajaran lebih interaktif yang menyenangkan sehingga setiap siswa dapat menguasai permainan yang bersifat memberi banyak pengetahuan yang berdampak pada hasil belajar.Walaupun belum $100 \%$ siswa kelas XII IIS 4 SMA negeri I Pancur Batu melakukan pembelajaran daring karena ada beberapa kendala yang penyelesaianya perlu dilakukan kerjasama antara sekolah, orang tuasiswa, komite, dinas terkait dan steakholder.

\section{KESIMPULAN}

Simpulan yang diperoleh dari penelitian ini adalah terdapat peningkatan keaktifan siswa dalam pembelajaran daring melalui media game edukasi quiziz pada masa pencegahan penyebaran Covid-19 mata pelajaran Bahasa Indonesia kelas XII MIA 1 SMANegeri 1 Pancur Batu semester ganjil tahun pelajaran 2020/2021. Setelah pelaksanaan pembelajaran daring melalui media game edukasi quiziz pada siklus I diperoleh rata-rata siswa yang aktif $56,25 \%$ dari 23 siswa, sedangkan siklus II diperoleh rata-rata $73,9 \%$. Jadi, media game edukasi quiziz dalam pembelajaran daring dapat meningkatkan keaktifan siswa pada masa pencegahan penyebaran Covid19 mata pelajaran Bahasa dan Sastra Indonesia kelas XII IIS 4 SMA Negeri 1
Pancur Batu semester ganjil tahun pelajaran 2020/2021 sebesar 17,65\%.

\section{DAFTAR PUSTAKA}

Arikunto, Suharsimi, dan Supardi Suhardjono. (2015). "Penelitian Tindakan Kelas Edisi Revisi." Jakarta: Bumi Aksara.

Arsyad, A. (2014). Media Pembelajaran. Jakarta: PT. Raja Grafindo Persada.

B. Josie Susilo Hardianto. (2020). Penyebaran Covid-19 Meluas. Diakses dari https://kompas.id/baca/intern. 28 Februari 2020 Henry, S. (2010). Cerdas dengan Game. Jakarta: PT Gramedia Pustaka Utama.

Baharuddin dan Esa. 2009. Teori Belajar dan Pembelajaran. Yogyakarta: Ar Ruzz Media.

Suprihati, Ningrum. 2014. Strategi Pembelajaran. Yogyakarta: Ar Ruzz Media.

Sardiman. 2014. Interaksi dan Motivasi Belajar mengajar. Jakarta: Rajawali Pers.

Hanafiah dan Suhana. 2010. Konsep Strategi Pembelajaran. Bandung: PT. Refika.

Wahono, Romi Satria. 2008. Pengantar e. Learning dan pengembangannya. ( online) Avalaible. http: //ilmukomputer.org/2008/11/25/peng antar-e learning dan pengembangannnya.

Zulfikri. 2008 Aktivitas Belajar. Jakarta: Depdiknas. 